\title{
Mexican Beef Industry Cluster Model for Increased Competitiveness
}

\author{
Antonio Emmanuel Perez Brito, Martha Isabel Bojorquez Zapata
}

${ }^{1}$ Universidad Autonoma de Yucatan

\begin{abstract}
This paper proposes a cluster model to boost competitiveness within the beef industry of the state of Yucatán, Mexico, through analysis of the environment using Porter's diamond (Porter, 1990). The study was qualitative, transverse, and included no experimental stages. Information was obtained through interviews with directors of the most important livestock associations within the state, from the Regional Livestock Union of the east, to businessmen and feed merchants, public officials, researchers, academics, and service suppliers. Development of a strategic cluster model will allow Yucatán beef producers to establish and continue innovation to strengthen their competitive advantage.
\end{abstract}

Keywords: Competitiveness, Bovine Livestock Industry, Cluster, Strategy.

\section{INTRODUCTION}

In 1996, Porter wrote that many activities such as creating, producing, selling, and delivering a product or service are basic units of competitive advantage.

Collis and Rukstad (2008) added that any strategic statement should start with a definition of the main goals to be achieved. "If you don't know where are you going, you'll choose any road". Competitive advantage is the essence of strategy and will define all the important ways to reach the established goals.

More recently, Vera and Ganga (2007) described world clusters as strategies that generate competitiveness in countries and regions. However, it is important to identify the constituents of a cluster and not confuse them with trade agreements between companies.

According to the Beef Cattle Research Council (BCRC, 2012), the design and development of a livestock cluster in Canada has allowed the integration of resources and alignment of research in order to improve the competitiveness of the sector. Among the achievements are: the improvement of product value (meat quality and optimization of resources) and an increased production efficiency (food, health, and animal welfare efficiency, and a reduction in diseases that limit production and grassland productivity).

Meat is an important food item consumed worldwide. According to the OECD, in a global context, increasing population and economic growth are factors that significantly influence global meat consumption levels. Meat consumption is influenced by income levels, and thus is an indicator of economic prosperity (OECD, 2009; FAO, 2013).

According to the Food and Agriculture Organization of the United Nations (FAO, 2013), livestock accounts for $40 \%$ of the global value of agricultural production, and forms the basis of livelihood and food security for nearly a billion people. The livestock industry, driven by the increase in incomes and supported by technological and structural change, is one of the fastest-growing segments of the agricultural sector. The progress and transformation of the sector offer opportunities for agricultural development, poverty reduction, and improvement of food security.

González (2006) has commented that livestock raising is undertaken throughout Mexico, and that $56 \%$ (approximately 110 million hectares) of national territory is dedicated to this activity. The System of National Accounts in Mexico, developed by the National Institute of Statistics and Geography (INEGI, 2010), notes that Yucatán's agricultural and fisheries sectors constitute $6.7 \%$ of the total Gross Domestic Product (GDP) of Mexico. 
According to Anderson et al. (2012), beef production is a significant economic activity in Yucatán, because it is undertaken over approximately $30 \%$ of the territory. They also suggest that the area to the east of Yucatán recorded the highest number of beef cattle.

The agricultural sector in Yucatán faces several challenges: disorganization of beef producers in the region; problems in the integration of the various links in the production-consumption chain (Hernández et al., 2011); unemployment resulting from limited job opportunities that results in labor migration to other regions (Martinez et al., 2012); lack of effective marketing strategies to ensure higher sales, market diversification, and the use of intermediaries in marketing (Fava et al., 2012); lack of technology and knowledge, and limited financial resources to generate innovative production units and value-generation for all activities; and finally, market competitiveness (Vera and Ganga, 2007).

In Yucatán, livestock has been an interesting investment alternative for some businessmen. As an activity, it has seen a small but steady upward trend since the fifties. Despite this, it has never become a key branch of the Yucatecan economy. Likewise, although increasing, the contribution of Yucatán's livestock production nationally has remained quite low over the last 25 years.

The objective of this investigation was to propose the development of a cluster model to boost competitiveness and generate benefits for beef producers in Yucatán.

\section{LiterATURE REVIEW}

\subsection{Strategy and Competitiveness}

According to Porter (1982), a strategy is a powerful force that defines targets aimed at achieving competitiveness at both local business and international levels. Although adopting a global strategy is risky, many companies that adopt changes in the way they plan, control, and operate can dramatically improve their positions. However, a global strategy requires managers to adopt new ways of thinking, otherwise they will not be able to recognize the nature of competition, justify the necessary investments, or sustain the necessary change in everyday behavior. He also notes that, in addition to the effectiveness and the cost advantage, a winning global strategy always requires skills in two other dimensions, distribution and finance.

From the point of view of Dussel et al. (1997), the basis for growth and permanence of a company lies in the design of strategies that make it competitive. The latter is achieved through a process of planning and control that evolves from the owner through to the ultimate areas of responsibility; it is important to set goals and targets for each area in such a way that they match the targeted direction.

In order to understand the behavior of local companies in developed environments with regard to competitiveness, it is important to understand the driving forces.

According to Drucker (1999), an effective business strategy should consider the following five aspects: (1) the falling birth rate in the developed world, (2) changes in income distribution, (3) redefinition of performance, i.e. that it involves balancing short-term results with long term prosperity, (4) that global competitiveness imposes an obligation to achieve productivity levels set by world leaders and the need to operate in a globalized economy, and (5) policy fragmentation.

According to Porter (2008), competitive positioning through the adoption of a strategy arises from three main sources:

- The position can be based on developing a subset of products or services of a specific industry, in what is called range-based positioning.

- A second positioning base lies in satisfying many or all of the needs of a particular group of customers; this is known as needs-based positioning.

- The third foundation of positioning is the segmentation of customers who can be accessed in different ways; this is known as access-based positioning.

- The same author notes that the development of clusters is a strategy to increase regional competitiveness.

\subsection{The Cluster as a Competitiveness Strategy}

There is no globally accepted concept associated with the term 'cluster'; several authors use it to define any spatial agglomeration of a particular economic activity (Vera and Ganga, 2007). 
To Weber (1929) and Hoover (1937), clusters represent a strategy to generate economic benefits in what they called agglomeration economies; they also refer to the concept of scale economies, in other words, cost savings by the companies that make up the cluster because of the increased volume of purchases.

According to Schmitz (1995), clusters arise because they allow the generation of competitive advantages among their members.

Authors such as Almquist et al. (1998, p. 14) consider clusters to be "synonymous with industrial networks".

Ramos (1998, p. 108) describes a cluster as a sectorial and/or geographical concentration of companies working in similar activities that are closely related, both backwards and forwards, to suppliers of inputs and equipment. There are also sideways links to processing and user industries as well as to services and activities that are closely related to important and cumulative external economies; there is agglomeration and specialization through the presence of producers, suppliers, skilled labor, and services relating to the sector, and the possibility of carrying out joint actions in search of collective efficiency.

For Vila et al. (2000), three basic dimensions define a cluster:

Territorial dimension: businesses are located in a specific geographical area, either more or less extended, or confined.

Sectorial dimension: companies are linked to a specific industrial value system.

Cooperative dimension: companies maintain relationships of cooperation and complementarity between themselves.

The key to understanding a cluster lies in "a conglomerate's ability to generate competition among all members" (Altenburg, 2001, p. 7). In addition, it is said that "a cluster is an agglomeration of a significant number of companies in a defined geographical area that has a clear specialization profile and in which the extent of division of work and interaction between companies is high" (Altenburg, 2001, p. 8).

Companies often have many relationships with other firms and institutions within and outside the same geographical region. There should be differentiation between business networks with a territorial approach (clusters) and functional networks. At the same time, functional networks can be divided into horizontal networks (cooperative schemes between groups of external companies, often from the same productive chain link) and vertical networks (relationships with supplier companies that represent different links (Dini, 2001, p. 8)).

Hoen (1999), as quoted in Navarro (2002), establishes that theoretical studies regarding the cluster are based on the concept of innovation as a key generator of economic growth; however, because of the availability of information, empirical studies are based on the analysis of the value chain.

Almquist et al. (1998, p. 7) and Baptista, (1998, quoted in Navarro, 2002) mention that "the locational externalities that occur in a cluster would be, instead, the effects that are generated for a company or sector as a result of its proximity to a territorial concentration of enterprises or industries related to their activity".

The clusters in most cases form cross-sectoral networks (vertical and lateral) comprising complementary companies specialized in a specific knowledge base in the value chain. (Navarro, 2002, p. 4)

To Grajirena et al. (2003), clusters extend vertically in the value chain, and include suppliers and ancillary industries, and extend laterally (horizontally or transversally) to technology and related sectors. Many others often include public institutions, educational institutions (universities, specialized academic centers, etc.), technology parks, information services, recycling, and technical support.

There are further factors such as spatial mobility (Krugman, 1991) and vertical relationships between companies (Venables, 1993, quoted in Otero, Lódola, and Menédez, 2004) that explain the agglomeration of activities in a particular region. 
Clusters can also be understood as a set of similar activities that are geographically delimited, with channels for commercial transactions, communication and dialogue, that share a specialized infrastructure, job market, and service market, and also face common opportunities and threats. (Rosenfeld, 1996, quoted in Otero et al., 2004, p. 7). This author emphasizes the importance of location in the cluster, and how this helps to increase competitiveness in the companies and industries involved.

To Porter (2008), clusters are geographic concentrations of interconnected companies, specialist suppliers, service suppliers, companies in related sectors and institutions (for example, universities, standards institutes, and trade associations), which are in competition but which also cooperate. The creation of clusters is typified by the presence of critical masses of unusual competitive success in particular areas of activity; it is a characteristic of all, or almost all, national economies, and of regional and even metropolitan areas, especially in the most economically advanced countries.

Poter (2008) notes the importance of identifying the constituent parts of the cluster, as follows:

- Recognize the existence of a large company or a concentration of companies in an ascending or descending search of a given vertical chain of companies and institutions.

- Carry out a horizontal investigation in order to identify industries that use common channels or that produce related products or supplementary services. Additional horizontal industry chains may be recognized based on the use of similar specialized inputs or technologies, or through supplier-side connections.

- Identify the cluster industries and institutions that provide specialized skills, technology, information, capital or infrastructure, and any connecting organization that includes the participants in the cluster.

- Look to government or any other regulatory body that has significant influence with the participants in the cluster.

According to Vera and Ganga (2007), clusters currently play an important role in defining public policies and the ways in which they interrelate to innovate and improve competitiveness. The universal pattern refers to companies that are related through the value chain, that are located within a defined geographical area, and that have a clear potential for achieving collective efficiency in doing business together. They are related to one another not only for competitive purposes, but also in order to cooperate, to add value, and to create a competitive advantage for the overall conglomerate of companies. The important aspect is not the relationship between the companies themselves; rather, it is their quality in working together, which is achieved by a focus on shared technologies with developmental possibilities and on innovation.

According to the authors, clusters take a decade or more to truly mature and to develop a competitive advantage. Clusters represent the centers of world economies from which the economic growth of nations is encouraged; they represent a cooperative strategy that generates collective efficiency, and improves the competitiveness of the members.

Prejmerean (2012) has shown that policies and strategies for economic development in an era of globalization have changed so as to focus on competitiveness based on investment and economic growth, and towards a vision based on innovation, knowledge, and network links. Although globalization dissolves the boundaries between countries, this involves a decrease in regional importance.

Globalization emphasizes the role of the regions, and the importance of developing the strengths of a given region as a policy to promote investment. Financial programs for the development of local production systems, the maintenance of industrial conglomerates, the implementation of regional innovation models, or the creation of regional knowledge, help to make a region more attractive for economic growth. For this author, the cluster is a concept that includes all of the above ideas and achievements.

With the development of economic activities in a region, people and companies can benefit greatly in terms of money, time, transaction costs, infrastructure, etc.

\subsection{Tools for Strategic Competitive Analysis: Diamond of National Advantage}

Porter (1990) searched for an answer to the following questions: Why are certain companies located in certain countries able to achieve innovation? Why are they able to overcome the barriers of change 
and innovation and achieve success? He went on to develop a model that is based on four attributes of a nation, attributes that individually and as a system constitute the 'diamond of national advantage', in other words, the playing field that each nation establishes and operates for its industries. These attributes create a national environment where companies are born and learn how to compete.

The attributes of Porter's diamond are as follows:

- Conditions of the factors: the position of a nation in relation to the factors of production, such as labor skills or infrastructure, without which it is not possible to compete in a particular industry. In sophisticated industries that form the backbone of any advanced economy, a nation does not inherit factors; in fact, the opposite takes place, it creates the most important factors of production, such as skilled human resources. The essential factors of production are those that involve sustained and abundant investment and that are specialized. To sustain a competitive advantage, a factor may be highly specialized to meet the particular needs of an industry. Nations succeed in those industries in which they are particularly good at creating such factors. Competitive advantage comes from the presence of world-class institutions that first create specialized factors and then continually work to update them.

- Demand conditions: This refers to the nature of market demand in relation to local products or services. Nations gain a competitive advantage in industries where local demand provides clear information to companies about new buyer needs.

- Advantages are also gained in industries where buyers pressure companies to innovate quickly, allowing them to achieve more sophisticated and competitive advantages than foreign rivals.

- Local demand helps build a competitive advantage when a segment of a particular industry is larger or more visible in the domestic market than in foreign markets.

- Related and support industries: This refers to the presence or absence in a nation of suppliers to a range of different industries, such as other, related, industries that are internationally competitive. Companies within a nation benefit when their suppliers are global competitors; however, this does not mean that all providers have to be competitive for a competitive advantage to be generated.

- Company strategy, structure, and rivalry: describes the national regulatory environment as it relates to how companies are created, organized, and administered, as well as the nature of domestic competition. Competitiveness in a specific industry results from the convergence of management practices and organizational models in the country concerned and the sources of competitive advantage in the industry. Countries differ markedly in the goals that companies and individuals pretend to achieve.

Companies reflect the characteristics of national capital markets and remuneration practices for managers. Individual motivation to work and to apply the necessary skills is also important for developing competitive advantage. Nations tend to compete in activities that people admire or that they depend on; in other words, the activities in which national heroes emerge. Domestic rivalry creates pressure on companies to innovate and improve. Local rivalries incentivize companies to reduce costs, to improve product or service quality, and to create new products and processes.

\subsection{Bovine Livestock Industry}

Based on the information obtained from Secretaría de Agricultura, Ganadería, Desarrollo Rural, Pesca y Alimentación [SAGARPA] (2012), food accounts for 22.7\% of the expenditure of Mexican households. Of this expenditure, one in three Mexican pesos is used to buy livestock products (poultry, turkeys, pigs, cattle, sheep, and goats). In Mexico, about 1.9 million tons of beef is consumed annually, which means a per capita consumption close to $17 \mathrm{~kg}$. The country is a net importer of beef, with a deficit estimated at 578 million dollars in 2011, equivalent to 138 thousand tons of meat. However, this deficit has gradually reduced since 2008, along with an increase in exports and a decline in imports.

The same information source notes that the most important livestock capital is in the hands of private producers, whose ranches contain most of the national herd. In 2013, the value of livestock production was more than two billion pesos. Beef production in Yucatán is dominated by entrepreneurs with an average farm size of between 1000 and 5000 hectares, although some farmers own many ranches. The largest farms are found in the east (in the Tizimin area); however, despite their size, they lack the 
technology to streamline their processes and they do not have the marketing plans, new product development or financial resources to survive. There are also major problems in obtaining credit to enable them to access new markets.

\section{MATERIALS AND MeTHODS}

Qualitative research was used in this study; it had a transverse temporal dimension with no experimental stages. The information used was from 2013. A representative sample of the Yucatán livestock region was examined.

To analyze Porter's tools, and the cluster, we collected information based on the review and analysis of all available relevant documentation, such as official statistical data banks, both national and international, and particularly from the state of Yucatán. Forty structured interviews were carried out, together with a questionnaire consisting of twenty-five questions, with the managers of the eleven livestock associations of the state, representatives of the regional livestock union of east Yucatán, businessmen and animal feed suppliers, and public officials, researchers, academics, and service providers. Data was also collected from distributors and traders of the main inputs for livestock production and from a number of producers, developers and calf rearers. The analysis methodology of Porter (2008) was used for gathering information from the interviews.

The interview and questionnaire methodology underwent some revision, mainly through an exhaustive review of related literature and reviews by experts (content validity) and after analyzing the theories proposed by the different authors mentioned in the literature review. For this study, the strategy concept, competitiveness and cluster model from Porter's (2008) conceptualization was adopted.

\section{RESUltS AND DisCUSSION}

The mean age of ranches was 31 years, employing an average of 27 full-time workers working with an average of 1120 head of cattle on an area of 1306 hectares. Mean owner age was 57 years.

\section{Regional Analysis through the Diamond of National Advantage}

\section{Factor Conditions}

In Yucatán, the average education level of the population aged 15 and over is 8.2.

In Mexico, individuals aged 15 and over have completed high school (the average educational level is 8.6). This puts the state in third place out of thirty-two states nationally with regard to the average educational level (INEGI, 2012). This factor limits the state with regard to the availability of a specialized workforce that can participate in industries that require advanced skills, such as the beef industry.

Apart from education, the state of Yucatán has other important features that are necessary for the development of the livestock industry and clusters. The most important are: a good road infrastructure, and good maritime connections to other countries; and with respect to electricity costs, overall agricultural activity consumes only $3.2 \%$ of the national total (Secretaría de Energía, 2011).

It should also be noted that the region has a suitable climate and vegetation for livestock.

\section{Strategic Considerations, Infrastructure and Competitiveness}

The agricultural sector attracts the lowest amount of foreign direct investment (IED); $100 \%$ of this sector participates with the $0.3 \%$; the livestock subsector is involved with the $0.1 \%$ and the state of Yucatán receives the $0.2 \%$ of the national IED, which places it in 25th position (Secretaría de Economía, 2013). However, the state of Yucatán is located between the lower corruption index (Transparencia Mexicana, 2012), which helps business development.

The state ranks 16th nationally in terms of a scale established by the World Bank Group (2013), an index that measures the ease of doing business.

\section{Related and Support Industries}

Livestock Associations are located in each of the municipalities in the livestock region; furthermore, there is the Regional Livestock Union of the east of Yucatán (in Spanish UGROY), which brings together all livestock associations. They are also suppliers of raw materials for the livestock industry. 
In the production and processing of beef in Yucatán, two companies lead the production chain and they have successfully integrated the activities of reproduction, fattening, slaughter, and meat processing.

\section{Demand Conditions}

According to SAGARPA (2012), in Mexico there has been an increase in meat consumption (beef, pork, poultry, sheep, and goats) per capita; in 1970 it was $23 \mathrm{~kg}$; in 1990, $34 \mathrm{~kg}$; and in 2013 it was around $63 \mathrm{~kg}$.

Livestock production in Central America has gone through a very protracted difficult period. This has led to a decrease in the number of beef herds, significant decreases in meat production, loss of participation in the international meat market, and a growing dependence on imported meat for local consumption. In the intra-regional market, both México (several bilateral free trade agreements have been signed) and the United States offer great potential, (FAO, 2013).

\section{Government}

\section{a. National Strategies}

The livestock sector adheres to the National Development Plan 2013-2018, in which it seeks to boost the sector's development through investment in physical and human capital. The trade agreements that Mexico has with Latin America, North America, the European Union, the Asia-Pacific region and Africa will strengthen the sector. Trade agreements with Africa will take time for bring benefits, though this continent is now recording economic growth.

National support programs for producers such as SINIIGA, PROGAN, sanidad animal, alianza contigo, and sacrifico TIF are developing financing schemes that allow capitalization within the sector. They are creating programs that aim to buy inputs and sell products, to offer capital loans to buy cattle and inputs, and to offer fixed-asset loans for rearing calves, for infrastructure, and for slaughterhouses.

Activities are also being developed to strengthen the position of Mexican meat, through marketing, advertising, market research, and marketing channel diversification, such as the promotion campaign for Mexican meat (TIF) in México and the international market. Furthermore, there is promotion of regional market studies in México, USA, Asia, and Europe, and promotion of partnerships with butchers.

\section{b. Strategies at the State Level}

The State Development Plan 2012-2018 considers the following:

The priority of a rural development policy is to create organized agriculture and fisheries that are organized and coordinated, with joint participation between producers and businessmen, and with the agreement of all federal and state agencies linked and focused on a single goal. The object is to achieve effective support programs, so as to increase productivity in Yucatán using a regional approach.

\section{Contingencies}

- Hurricanes

- Drought

- Increase in input prices

\section{CONClusion}

According to the results of the current study, it may be concluded that the State of Yucatán has the structure to develop a local cluster in the livestock sector. Worldwide competitiveness is rooted in the competitiveness of towns and metropolitan areas, so it is important for rural areas to be competitive.

The development of a strategic cluster model will allow Yucatán beef producers to establish continuous innovation to strengthen their competitive advantage, and to implement more productive human and physical resources, which will lead to improvement in the four sides of Porter's diamond. 
Furthermore, the cluster will generate internal competition between members that will boost the competitiveness of the livestock sector.

Although it has been concluded that Yucatán has the structure to develop a local cluster, the following proposals, thought to be necessary for the success and permanence of the cluster, were made:

- To have certified workers in order to use the most sophisticated technology in breeding and fattening beef cattle.

- Take advantage of economy of scale in the production and distribution of new food products. They could also increase the production of high-range products. Finally, they should tend to focus on the growth of external sales to countries with a high consumption and high growth and those that have commercial agreements with China and Vietnam.

- Farmers and related industries should invest in research in order to develop local technology, in relation to biotechnology and equipment.

- It is necessary to improve local competition and cooperation abroad. As there are high fixed costs for entering new global markets, strategic alliances could be made between producers to move into foreign markets.

- The government has an important supportive role to play in increase the competitiveness of the livestock sector in Yucatán through clustering. Excessive tax burdens are an important obstacle to operations. The government should focus on fair taxation that stimulates the development and competitiveness of the sector. At the same time, it should continue to promote access to equitable financing for beef producers. Moreover, the state and municipal governments must improve and continue with the maintenance of the existing transport infrastructure, which will be reflected in lower operating costs and renewed attractiveness of the region as a whole.

- The government should encourage national production to meet the internal market and to some extent, the external market, because scarcity stimulates imports. They should also encourage integration of producers and value chains that encourage direct sales to consumers.

- Farmers need to improve the quality of their cattle breeds.

Our study is unique because the results obtained have important practical implications for the sector. The livestock industry in Yucatán represents one of the main strategic activities of the state but faces a serious problem of competitiveness. A more competitive livestock sector would lead to improved economic growth, sustainable human development, and social integration. Economic and environmental improvement involves the creation of economic value in a way that also generates a shared value for society.

In this regard, it is suggested that clusters should be created in other important strategic sectors in the state of Yucatán, such as manufacturing, tourism, and other parts of the agricultural sector. Furthermore, this study can be used in other states that may also propose the clustering of economically important sectors.

The current study contributes to existing literature on the beef industry on Mexican ranches, and it informs the administrators and/or owners about the weaknesses to be overcome in order to become more competitive. This study could also orient owners to enable them to adopt strategic models and methodologies that will boost the competitiveness of the sector, as well asto generate value-added products, thereby ensuring their position in competitive markets. The study could further enable the Mexican government to understand the challenges faced by the livestock industry, and the related support available through public policies, such as generating sources of wealth and employment, to contribute towards gaining more access to sources of funding for new investments. This study could be beneficial for institutions of higher education for incorporation into programs of study including the linkage programs and continuing education on topics related to strategic cattle management. Most importantly, it aims to continue promotion of the generation and application of innovative knowledge, through professors, researchers, groups, and/or research networks, in the region, the nation, and internationally. Within Research limitations/implications, it is worth noting the context in which this information can be applied. 


\section{REFERENCES}

[1] Almquist, G., Norgren, L. and Strandell, A.C. (1998), Clusters and cluster policy in Sweden. NUTEK, Suecia.

[2] Altenburg T. (2001), La promoción de clusters industriales en América Latina, Focopyme, Argentina.

[3] Anderson, S., Santos, J., Boden, R. and Wadsworth, J. (2012), "Characterization of Cattle Production Systems in the State of Yucatan. Dual Purpose Cattle Production Research". Fundación Internacional para la Ciencia. Vol. 40 No. 2, pp. 187-192.

[4] Beef Cattle Research Council. (BCRC, 2012), "National Beef Value Chain Roundtable". National Beef Research Strategy. No. 1, pp. 1-60

[5] Collis, D. and Ruckstad, M. (2008), "Can You Say What your Strategy Is?". Harvard Business Review. No. 1, pp. 82-90

[6] Dini, M. (2001), La promoción de clusters industriales en América latina. Focopymes, Argentina.

[7] Drucker, P. (1999), Management Challenges for 21st Century. Harper Business, New York Estados Unidos.

[8] Dussel, P., Piore, M. and Ruiz, C. (1997), Planeación Estratégica para la Pequeña y la Mediana Empresa., Promesa, México.

[9] Fava, M., Canto, F. and Melo, M. (2012), "Competitiveness of brazilian beef chain. Brasil". IFAMA. Vol. 50 No. 9, pp. 1-13.

[10] Foro Consultivo (2013), "Acertadístico". Recuperado el 22 de agosto de 2013, de http://www.foroconsultivo.org.mx/documentos/acertadistico/conacyt/sistema_nacional_de_inves tigadores.pdf

[11] González, E., (2006), La Sanidad y el Estado Sanitario del Hato Nacional de Bovinos para Carne. CONASA, México.

[12] Grajirena, J., Gamboa, I. and Molina, A. (2003), "Los clústers como fuente de competitividad: el caso de la comunidad autónoma del país Vasco". Cuadernos de Gestión. Vol. 1 No. 4, pp. 55-67.

[13] Hernández, J., Rebollar, S, González, F., Guzmán, E., Albarrán, P. and García, M. (2011), "La cadena productiva de ganado bovino en el sur del estado de México". Revista Mexicana de Agronegocios. Vol. 29 No. 15, pp. 672-680.

[14] Hoover, E. (1937), “Spatial price discrimination”. Review of Economic Studies, No. 4, pp. 182191.

[15] Instituto Nacional de Estadística y Geografía. (INEGI, 2010), "Censo de Población y Vivienda 2010”. Recuperado el 15 de octubre de 2013, de http: // operativos.inegi.org.mx / sistemas / iter / entidad_indicador.aspx?ev $=5$

[16] Instituto Nacional de Estadística y Geografía. (2010), "XIII Censo General de Población y Vivienda 2010". Recuperado el 22 de agosto de 2013, de http://www.inegi.org.mx/est/ contenidos/proyectos/ccpv/cpv2010/presentacion.asp

[17] Instituto Nacional de Estadística y Geografía. (INEGI, 2012), "Dinámica". Recuperado el 15 de octubre de 2013, de http : // cuentame.inegi.org.mx / monografias / informacion / yuc / poblacion $/$ dinamica.aspx?tema $=$ me\&e $=31$

[18] Instituto Nacional de Estadística y Geografía (INEGI, 2012), "El sector alimentario en México, 2012". Recuperado el 15 de octubre de 2013, de: http : // www.inegi.org.mx / prod_serv / contenidos/espanol/bvinegi/productos/integracion/sociodemografico/SAM/2012/sam2012.pdf

[19] Krugman, P. (1991), "Increasing returns and economics geography". Journal of Political Economy. Vol. 99 No. 3, pp. 483-499

[20] Krugman, P. (1992), Geografía y comercio. Antoni Bosch, España. 
[21] Martínez, V., Santos, J. and Montes, R. (2012), "Función de producción de la ganadería de doble propósito de la zona oriente del estado de Yucatán”. Técnica Pecuaria en México. Vol. 40 No. 2, pp. 187-192.

[22] Navarro, M. (2002), El análisis y la política de clústers. Universidad de Deusto. España.

[23] Organización para la Cooperación y el Desarrollo Económico., (OECD, 2009), "Información Básica del Sector Agropecuario, Subregión Norte de America Latina y el Caribe". Recuperado el 22 de agosto de 2013. de http : // www.oecd.org / pages / 0,3417, es _ 36288966 _36288120_1_1_1_1_1,00.htm

[24] Organización de las Naciones Unidas para la Agricultura y la Alimentación., (FAO, 2013). "El Estado Mundial de la Agricultura y la Alimentación". Recuperado el 22 de agosto de 2013, de: http://www.fao.org/docrep/018/i3300e/i3300e00.htm.

[25] Otero, G., Lódola, A. and Menédez, L. (2004), "El rol de los gobiernos subnacionales en el fortalecimiento de Clústers productivos". Recuperado el 22 de agosto de 2013, de http://www.ec.gba.gov.ar/ GIE/Investigacion/Archivos/Abril2004.pdf

[26] Porter, M. (1980), Competitive Strategy: Techniques for Analyzing Industries and Competitors. Harvard Business Press, Estados Unidos.

[27] Porter, M. (1982), "How Global Companies Win Out". Harvard Business Review. Vol 1 No. 50, pp. 98-107.

[28] Porter, M. (1990), The Competitive Advantage of Nations. Harvard Business Press, Estados Unidos.

[29] Porter, M. (1996), “What is Strategy?". Harvard Business Review. No. 1, pp. 59-79.

[30] Porter, M. (2008), On Competition. Harvard Business Press, Estados Unidos.

[31] Prejmerean, M. (2012), "The necessity of clusters for modern management". Review of International Comparative Management. Vol. 5 No. 13, pp. 778-793.

[32] Ramos, J. (1998), "Una estrategia de desarrollo a partir de los complejos productivos en torno a los recursos naturales". Revista CEPAL. No. 66, pp. 105-125.

[33] Rodríguez, J. (1999), Como aplicar la Planeación Estratégica a la Pequeña y Mediana Empresa. Editorial ECAFSA, México.

[34] Schmitz, H. (1995), "Collective efficiency: Growth Path for small-scale industry". Journal of Development Studies. Vol. 31 No. 4, pp. 529-566.

[35] Secretaría de Agricultura, Ganadería, Desarrollo Rural, Pesca y Alimentación. (SAGARPA, 2012), "Situación actual y perspectivas de la producción de carne bovino en México". Recuperado el 15 de octubre de 2013, de: http://www.ipcva.com.ar/files/mexico.pdf

[36] Secretaría de Economía. (SE, 2013), "Comisión Nacional de Inversiones Extranjeras". Recuperado el 30 de diciembre de 2013, de http : // www.economia.gob.mx / files / comunidad_negocios/estadistica_oficial_ied/informe_congreso_3t_11113.pdf

[37] Secretaría de Energía. (SENER, 2011), "Balance Nacional de Energía 2011". Recuperado el 30 de diciembre de 2013, de http://www.sener.gob.mx/res/PE_y_DT/pub/2012/BNE_2011.pdf

[38] Transparencia Mexicana. (2012), "Índice Nacional de Corrupción y Buen Gobierno". Recuperado del 30 de diciembre de 2013, de http://www.tm.org.mx/wpcontent/uploads/2013/05/01-INCBG-2010-Informe-Ejecutivo1.pdf

[39] Vera, J. and Ganga, F. (2007), "Los Clústers Industriales: Precisión Conceptual y Desarrollo Teórico". Cuadernos de Administración. Vol. 20 No. 33, pp. 303-323.

[40] Vila, M., Ferro, C. and Rodríguez, M. (2000), "Agrupamientos sectoriales territoriales (A.S.T.): reflexiones acerca de los recursos compartidos". Revista de Economía y Empresa. Vol. 40 No. 14, pp. 87-101.

[41] Weber, A. (1929), Theory of the location of industries, University of Chicago Press, Chicago.

[42] World Bank Group. (2013), "Doing Business". Recuperado el 30 de diciembre de 2013, de http://www.doingbusiness.org/data/exploreeconomies/mexico/sub/mérida/ 


\section{AUTHORS' BIOGRAPHY}

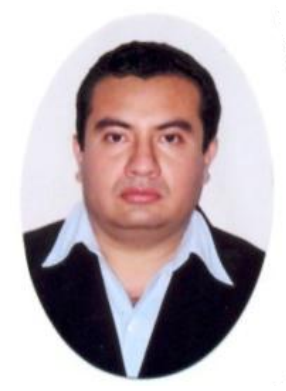

Antonio Emmanuel Perez Brito, Ph.D. from Universidad Popular Autonoma del Estado de Puebla (August 2014), is Professor of finance at the Facultad de Contaduria y Administracion of the Universidad Autonoma de Yucatan. Current research interestsinclude competitiveness, financial management, and corporate finance.

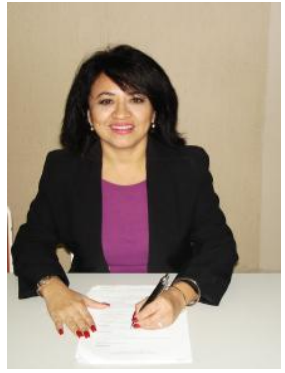

Martha Isabel Bojorquez Zapata, Ph.D., from Universidad del Sur (March 2013), is Professor of finance at the Facultad de Contaduria y Administracion of the Universidad Autonoma de Yucatan. Current research interestsinclude competitiveness, financial management, and personal finance. 